\title{
Educating Student Teachers to Become High Quality Professionals - A Finnish Case
}

HANNELE NiEMI ${ }^{1}$

$\propto$ For decades, the Finnish orientation toward teacher education has committed itself to the development of an inquiry oriented and research-based professional culture. The aims of teacher education are to train students to find and analyse problems they may expect to face in their future work. This study consists of a survey of student teachers $(n=545)$ in two universities in Finland. Web-based surveys with quantitative and qualitative questions were sent to all student teachers in the beginning of May 2010. Students assessed how teacher education had provided them with the competences they need in a high standard profession, what kinds of active learning experiences they had in their TE studies, and how research studies of teacher education had contributed to their professional development. The participants of the study assessed that they had achieved good skills in planning teaching and curricula. They were capable of using different teaching methods. They were aware of their own teaching philosophy and their responsibilities as professionals and life-long learners. They consider the research component of TE valuable to their independent and critical thinking. They were very engaged in studies. Finnish pre-service teacher education seems to function very well and to be effective in providing the skills teachers need to work as independent professionals. The results of the study show, however, that students also need more supervision and guidance on how to collaborate with parents and other stakeholders outside school, such as representatives of working life as well as partners in business life and culture.

Keywords: Active learning, Professional development, Student teachers, Teacher education, Teachers

1 University of Helsinki, Institute of Behavioural Sciences 


\section{Introduction}

Finnish teacher education has received a great deal of attention because of the high learning outcomes of Finnish 15-year-old students in Pisa achievement testing. Finland was in the highest position or among the three best countries in 2000, 2003, 2006 and 2009 (OECD). Many researchers, as well as Finnish policy makers, regard high quality teachers and teacher education as one of the major factors in good learning outcomes.

During the last twenty years, Finnish teacher education has been evaluated systematically in many national and international evaluations. Many research projects and doctoral dissertations on some components of teacher education have also provided important knowledge for further development (e.g., Buchberger et al., 1994; The Committee Report, 1994; Finnish Higher Education Evaluation Council, 2011; Jussila \& Saari, 1999; Ministry of Education, 2007; Niemi, 1996; Niemi, 1999; Niemi \& Kemmis, 1999; Niemi \& Kohonen, 1995).

Some of the evaluations have focused on structural and higher education policy issues, while some have concentrated on themes of teachers' professional development in teacher education. The present study belongs to the latter evaluations.

This study aims to investigate how student teachers in two universities assess their experiences and learning outcomes in teacher education.

Because there are both structural and content-based differences between elementary and secondary teacher education, one of the aims of the study is to investigate what the major differences between assessments of primary and secondary school student teachers in professional competences and skills are.

According to decrees issued in 1979 and 1995, all prospective teachers in Finland have to attain a master's degree as a teacher qualification. In terms of the Bologna process, the qualified teachers' degree is equivalent to the second cycle degree in the European higher education area (Niemi \& Jakku-Sihvonen, 2006). In the Finnish educational system, the combination of a three-year bachelor's degree and a two-year master's degree in appropriate subjects qualifies teachers to teach subjects in primary and secondary schools or general subjects in vocational institutions. This means that all other teachers must attain a master's degree (BA 180 European credits (ECTS) + MA $120=300$ ECTS; 1 ECTS is about 27 hours' work). 
Primary teachers, also called class teachers, have educational science as their major, and this degree requires the completion of a master's thesis. The topics of the theses can be highly school-related, and the theses are very often action research projects. Secondary school teachers, also called subject teachers, complete a major in their academic teaching subject and a substantial minor in pedagogy. Teacher education in universities does not follow any strictly defined programmes. Students have opportunities to create their own study plan selecting those modules required for teacher qualifications for different levels of the educational system. Nonetheless, teacher education departments offer certain study schedules in order to make studies effective and efficient.

Finland does not have any common national standards for teacher education. Each university is responsible for the quality of the programmes and studies they provide. The Teacher Education Act and relevant decrees provide frameworks and common guidelines; however, universities are free to modify their own courses and programmes. Even though there are no national standards there are many unofficial common principles and recommendations on which national TE working groups and Deans of TE educational departments have agreed. The following main structural guidelines were accepted in 2006:

The main elements of all teacher education curricula consist of studies in:

- $\quad$ Academic disciplines. These can be whichever disciplines are taught in schools or educational institutions or in the science of education. Academic studies can be a major or minors depending on the qualification being sought. Class teachers have a major in educational sciences and minors in other disciplines.

- $\quad$ Research studies consist of methodological studies, a BA thesis and a MA thesis.

- $\quad$ Pedagogical studies (min. 6o ECTS) are obligatory for all teachers. They also include teaching practice.

- Communication, language and ICT studies are obligatory.

- The preparation of a personal study plan is a new element in university studies in Finland. Its main function is to guide students to develop their own effective programmes and career plans, and to tutor them in achieving their goals. 
- Optional studies may cover a variety of different courses through which students seek to profile their studies and qualifications.

\section{Pedagogical studies}

The traditional distinction between class teachers and subject teachers has been retained, but the structures of the respective degree programmes allow students to take very flexible routes, to include both in the same programme or permit later qualification in either direction. Pedagogical studies (6o ECTS) are obligatory for qualification as a teacher and are approximately the same for both primary and secondary teachers. These studies give a formal pedagogical qualification to teachers of all levels in the Finnish educational system regardless of the programmes in which they are provided. They provide teachers' general competences with an emphasis on a reflective and researchbased orientation in the teaching profession. According to the law, pedagogical studies must be studies in the science of education. Pedagogical studies can be part of degree studies or they can be taken separately after the completion of a master's degree.

The goal of pedagogical studies is to create opportunities to learn pedagogical interaction, to learn how to develop one's own teaching skills, and how to plan, teach and evaluate teaching in terms of the curriculum, the school community, and the age and learning capacity of the pupils. Students should also learn how to cooperate with other teachers, parents and other stakeholders and representatives of the welfare society. (www.helsinki.fi/vokke)

Teachers' pedagogical studies also include guided teaching practice (approx. 20 ECTS). The aim of guided practical studies is to support students in their efforts to acquire professional skills in researching, developing and evaluating teaching and learning processes. In addition, students should be able to reflect critically on their own practices and social skills in teaching and learning situations. During guided practical studies, students should meet pupils and students from various different social backgrounds and learning orientations and have opportunities to teach them according to the curriculum.

An important aim of pedagogically oriented studies is also to educate teachers who are able to study and develop their own researched-based practices. For this reason, the modules on behavioural research methods are also obligatory for subject teachers. 


\section{Perspective and theoretical framework}

For decades, the Finnish orientation toward teacher education has committed itself to the development of a research-based professional culture (Niemi \& Jakku-Sihvonen, 2006). The aim of TE studies is to train students to find and analyse problems they may expect to face in their future work.

\section{Professional skills}

The measurements of professional skills are based on the paradigms of the reflective teacher, the teacher as a researcher, and inquiryoriented teacher education (e.g., Darling-Hammond, 2005, 2010; Niemi, 2002; Scardamalia, 2000; Smyth, 1995; Tabachnick \& Zeichner, 1991). The theoretical framework of professional skills also consists of a concept that takes a broad view of teachers' professional role in schools and society.

There are tensions in many countries on how the practical component of teacher education, e.g., teaching practice, should be integrated and implemented in teacher education programmes. As professionals, teachers need many practical skills that enable them to mediate academic subject knowledge, values and attitudes to individuals or groups. Teachers need the confidence to work with learners in real situations, and student teachers often ask for very practical advice on their teaching practice. Recent research on expertise has revealed that there are different phases in the development of individual expertise (Dreyfus \& Dreyfus, 1986). Student teachers also need different kinds of support in the different phases of their development.

In Finnish teacher education the aim is for teachers to be able to work as independent professionals in schools and to make an active contribution to educational issues including the development of school curricula, as well as formative and summative assessments of students' learning. These competences require strong expertise and the integration of different kinds of knowledge. Davenport and Prusak (1998) have found that an expert needs codified knowledge and organised official and literally transferable knowledge. In addition, the development of expertise requires role models, observing experts, tacit knowledge, a social network and even good stories of successful practice. Davenport and Prusak (1998) point out that experts' knowledge is deep personal knowledge that has been tested in practical situations.

According to Schön (1991), experts always face problems in 
situations that are unique and consist of uncertainties, value conflicts and other tensions because of complexity. They work in complex situations. This establishes special requirements for their knowledge base. Experts' knowledge is rational in nature, but this is not sufficient. They also need principles, rules and models, and they need to know how to apply scientific theories and techniques to complex problems.

Working as an expert means that one has the knowledge and practical abilities to work in complex situations. In addition, experts need confidence in two complementary ways (Isopahkala-Brunet, 2004): they need the self-confidence to carry out their expertise in demanding unique situations, and they also need to implement their expertise in such a way that their customers, stakeholders and colleagues trust them. In the teaching profession this means that students and parents, and even society at large, need to be able to trust teachers' expertise.

Although teachers need many specific skills they also need a comprehensive idea or vision of what their work as an educational expert means. Teachers need to understand the complexity of educational processes and see evidence that comes from different sources. They need research-based and research-informed knowledge, but they also need to be open to acquiring and assessing local evidence. Scardamalia and Bereiter (2003) have examined the behaviour of experts. The feature that really distinguishes experts from others is their approach to new problems. The pattern recognition and learned procedures that lead to intuitive problem solving are only the beginning. The expert invests in what Bereiter and Scardamalia call progressive problem solving, that is, tackling problems. Unlike reducing problems to previously learned routines, this increases expertise.

\section{Active learning}

How to get students to become more active learners is a very common problem in many countries. Active Learning research has revealed that teachers who seek to tutor their pupils to become active learners gain a new pedagogical role. They become facilitators who give more responsibility to students. They are more democratic; they negotiate more with students about aims, methods and control of learning. They see, more than before, all learners as resources for one another. New teaching methods, which consists of more independent learning, more collaborative arrangements, more open tasks and projects, enables students to collaborate with one another, but very often a teacher 
is also a partner in a learning team. A teacher's position is no longer at the front of the classroom, nor in the centre of the classroom, but s/ he is a circulating expert, learning together with students and trying to give as much space as possible to his/her students. To promote active learning, the teacher should be a tutor. In addition to the teacher, other partners (e.g., peers, parents, employers) in networks and co-operative projects should have a tutoring and supporting role. These scenarios of teachers' work create new demands on teacher education.

Hannele Niemi has investigated active learning in schools and teacher education (e.g., Niemi, 2002). The research focused on the Finnish case of active learning in teacher education and found that there are many factors that are obstacles to active learning. Schools, as well as teacher education institutions, change very slowly. We carry our learning culture from the early days of our own school life, and it forms our concepts and ideals as to what we regard as the aims of learning.

The framework of active learning assessment in this study is based on theories that consider learning as a constructivist and collaborative process. Active learning consists of independent inquiry, the structuring and restructuring of knowledge, a problem solving orientation, a critical approach and the evaluation of knowledge. The goals of learning are that the learner can elaborate on applications of knowledge and s/he is capable of producing new knowledge individually and collaboratively (e.g., Nonaka \& Toyama, 2003; Scardamalia, 2002; Sfard, 1998). Active learners develop their skills of inquiry and learn to reflect on and control their own learning processes (e.g., Pintrich \& McKeachie, 2003). Knowledge is not just an individual possession but is socially shared and emerges from participation in sociocultural activities. Learning is increasingly seen as building knowledge together. When seeking new ways for knowledge creation as an interactive process we see that all educational settings, including schools, should prepare students for 'virtuous knowledge sharing' (European University Association, 2007, p. 21).

\section{Research studies in teacher education}

An important aim of research oriented studies is also to educate teachers who are able to study and develop their own research-based practices. For this reason, modules on behavioural research methods are also obligatory for all TE students in Finland. The critical scientific literacy of teachers and their ability to use research methods are considered crucial. The goal of these studies is to train students to find and 
analyse problems that they may expect to face in their future work. Research studies provide students with an opportunity to complete an authentic project in which students must formulate a problem in an educational field, be able to search independently for information and data related to the problem, elaborate on them in the context of recent research in the area and synthesise the results in the form of a written thesis. They learn to study actively and to internalise the behaviour of how teachers may act like researchers in their work.

The research component is an essential part of Finnish teacher education. It comprises approximately $20 \%$ of the entire TE studies of both elementary teachers (major in Education) and secondary school teachers (major in Academic Subject). Despite initial difficulties in integrating research studies with other components of TE in the 1980s, research methods and the writing of a master's thesis are now among the best segments of elementary school teacher education (e.g., Niemi 2002; Niemi \& Kohonen 1995;). The general result of evaluations is that the more demanding the studies are, in terms of quality of learning, the more useful they are.

\section{The research}

In this research we investigate:

- How well do teacher education studies provide wide and comprehensive professional competences to student teachers?

- How do teacher education studies steer student teachers to become active learners?

- What kind of contribution does a research component in teacher education bring to student teachers' professional development?

\section{Data collection}

The study consists of a survey to student teachers with the following measures:

- Teachers' professional skills and competences needed in a high standard profession (40 questions)

- Student teachers' experience of active and collaborative learning in TE (20 questions) and 5 open-ended questions.

- Student teachers' experiences of the research component in teacher education and how research studies of teacher education had contributed to their professional development (20 questions). 
Most of the questions were structured items using a 1-5 scale. There were also open answers for qualitative descriptions of their experiences during TE. The questionnaires were based on the theoretical basis presented in the earlier chapter, on the guidelines and aims of the Act and Decrees of Finnish teacher education, as well as on national strategies, e.g., the use of ICT in schools.

The questionnaires on professional skills and competences and active learning had many of the same questions that had appeared in earlier surveys of Finnish teacher education (Niemi, 1995).

The open-ended questions were:

- Describe 1-3 learning situations or units in your university studies in which you experienced being a strongly active learner.

- What are the greatest obstacles to active learning in teacher education?

- How could teacher education give teachers the readiness to tutor pupils at schools for active and self-regulated learning?

Analysis methods of the study were quantitative and qualitative. The quantitative data has been analysed using descriptive statistics: means and standard deviations. In addition, correlate and multivariate methods were applied. Data reduction methods, such as Factor Analysis, were used (Principal axel method with Varimax and Promax rotations) in the analysis of the Active Learning questionnaire. The qualitative data has been analysed using content analysis techniques. The categories that describe student teachers' best active learning experiences will be presented in this study.

\section{Sample}

The data of this study were collected among students of class teacher and subject teacher education programmes at the Universities of Helsinki and Oulu. These two universities offer both primary and secondary teacher education degrees, with the main structures of TE being the same in both universities. In terms of contextual differences between universities, we can find some special features. The University of Oulu is a more technology oriented university and has many regional responsibilities to the locality. The University of Helsinki is an internationally recognised comprehensive university with an emphasis 
on basic research. Both universities have been actively involved in national cooperation to develop teacher education and follow joint agreed recommendations. Therefore, there is no hypothesis that these two universities would differ in assessments made by their student teachers. Both universities have a strong research oriented component in pedagogical studies as well as in subject matter studies. All students have to write both BA and MA theses in their major subject. Class teachers major in educational sciences whilst subject teachers major in academic subjects with a substantial minor in Education. Teaching practice is integrated with pedagogical studies from the beginning of the studies. (Jakku-Sihvonen \& Niemi, 2006).

Web-based surveys were sent to all student teachers in the beginning of May 2010 and the website was open until 4 June 2010. Departmental mailing lists were used in data gathering. The students could assess their TE studies anonymously. Two email reminders about the questionnaire were sent to the mailing lists. The official, total number of student teachers in both universities is approximately 1450 , consisting of 1000 class teachers (all students in 5 years programmes) and 450 subject teachers undertaking one year pedagogical studies. The exact numbers of students are very difficult to estimate because students have a lot of freedom to make their personal study plans, which can shorten or lengthen their study times. A total of 605 students visited the web-based interview sites, but the number of students who actually responded varies between sets of questionnaires and open ended questions. Around $30-42 \%$ of the total number of different student teachers' groups responded to the questionnaires. In comparison to general answer rates in web surveys we can view the achieved rate as good, or at least satisfactory. The background information about the respondents is outlined in Table 1. The total number of students in the survey is between 545-331, depending on the questionnaire. 
Table 1. Students in the web-based survey. The average time taken to answer the study was 51 minutes, median 24 minutes.

\begin{tabular}{|c|c|c|c|c|c|c|c|}
\hline & \multicolumn{2}{|c|}{$\mathrm{f}(\%)$} & \multicolumn{2}{|c|}{$\mathrm{f}(\%)$} & $\mathrm{f}(\%)$ & f $(\%)$ & $\mathrm{f}(\%)$ \\
\hline University & \multicolumn{2}{|c|}{$\begin{array}{l}\text { University of Oulu } \\
223(40.2 \%)\end{array}$} & \multicolumn{2}{|c|}{$\begin{array}{l}\text { University of } \\
\text { Helsinki } \\
332(59.8 \%)\end{array}$} & & & \\
\hline Gender & \multicolumn{2}{|c|}{91 Males (16\%) } & \multicolumn{2}{|c|}{464 Females $(83,6 \%)$} & & & \\
\hline Programme & \multicolumn{2}{|c|}{$\begin{array}{l}313 \text { class teacher } \\
\text { students }(56.4 \%)\end{array}$} & \multicolumn{2}{|c|}{$\begin{array}{l}236 \text { subject teacher } \\
\text { students }(42.5 \%)\end{array}$} & & & \\
\hline Age & $\begin{array}{l}<25 \text { years } \\
268 \\
(48.3 \%)\end{array}$ & $\begin{array}{l}25-43 \\
235 \\
(42.3 \%)\end{array}$ & $\begin{array}{l}35-44 \\
39 \\
(7 \%)\end{array}$ & $\begin{array}{l}45-55 \\
13 \\
(2.3 \%)\end{array}$ & & & \\
\hline Phase of studies & $\begin{array}{l}1 \text { year } \\
187 \\
(33.7 \%)\end{array}$ & $\begin{array}{l}2 \text { years } \\
128 \\
(23.1 \%)\end{array}$ & $\begin{array}{l}3 \text { years } \\
74 \\
(13.3 \%)\end{array}$ & $\begin{array}{l}4 \text { years } \\
69 \\
(12.4 . \%)\end{array}$ & $\begin{array}{l}5 \text { years } \\
55 \\
(9.9 \%)\end{array}$ & $\begin{array}{l}6 \text { years } \\
22 \\
(4 \%)\end{array}$ & $\begin{array}{l}>6 \text { years } \\
n=20 ; \\
(3.6 \%)\end{array}$ \\
\hline $\begin{array}{l}\text { Representatives } \\
\text { of different } \\
\text { school subjects }\end{array}$ & $\begin{array}{l}\text { Maths and } \\
\text { Science } \\
212 \\
(21.8 \%)\end{array}$ & $\begin{array}{l}\text { Foreign } \\
\text { languages } \\
81 \\
(14.6 \%)\end{array}$ & $\begin{array}{l}\text { Mother } \\
\text { tongue } \\
61 \\
(11 \%)\end{array}$ & $\begin{array}{l}\text { History } \\
\text { and Social } \\
\text { sciences } \\
32 \\
(5.8 \%)\end{array}$ & $\begin{array}{l}\text { Religion } \\
\text { and } \\
\text { Ethics } \\
33 \\
(5.9 \%)\end{array}$ & $\begin{array}{l}\text { All othe } \\
\text { options } \\
112 \\
(20.2 \%)\end{array}$ & major \\
\hline
\end{tabular}

\section{Results}

\section{Professional skills and competences}

The highest professional competences (Table 2) have been achieved in the following skills: (1) Designing of instruction, (2) Critical reflection on one's own work, (3) Becoming aware of the ethical basis of the teaching profession, (4) Life-long professional growth, (5) Self-evaluation of one's own teaching, (6) Using teaching methods, and (7 ) Development of one's own educational philosophy. All of these have a mean value of at least 3.5 and standard deviation is less than 1.0o. These are all high level professional skills necessary for experts who develop their own work. Very close to these skills are the following competences: Mastering academic contents of curriculum, Independent management of teachers' tasks, Commitment to teaching profession, Researching one's own work, Education of a student's whole personality, Critical assessment of teacher education, and Confronting multiculturalism. All of these have a mean value of at least 3.oo. 
The weakest skills student teachers have achieved are in administrative tasks and management of tasks outside a classroom (keeping an eye on students during recess, school festivals, trips, morning assemblies, etc.). Cooperation with parents, representatives of work life and cultural partners is also weak, as is working in cooperative action research projects, student welfare groups and other school community groups. Acting in conflict situations (as mobbing) was also a weak competence. All of these competences have a mean value under 2.5. A common feature of all of these skills is some kind of cooperation with partners outside the school community or tasks outside classrooms.

Table 2. How well has the teacher education you have participated in so far provided you with a readiness for the teaching profession? $(1=$ very weakly, $2=$ weakly, $3=$ fairly, $4=$ well, $5=$ very well). The skills are set in a ranking order. $\left({ }^{* * *}=<\mathrm{p} 0.001{ }^{* *}=\mathrm{p}<0.01{ }^{*}=\mathrm{p}<0.05\right)$

\begin{tabular}{|c|c|c|c|c|c|}
\hline $\begin{array}{l}\text { Professional } \\
\text { competence }\end{array}$ & $\begin{array}{l}M \\
(n=455)\end{array}$ & SD & $\begin{array}{l}\text { Differences } \\
\text { between } \\
\text { years in TE } \\
\text { df }=5,449\end{array}$ & $\begin{array}{l}\text { Differences } \\
\text { between } \\
\text { class } \\
\text { and subject } \\
\text { teachers } \\
\text { df }=1,454\end{array}$ & $\begin{array}{l}\text { Correlation } \\
\text { with } \\
\text { active } \\
\text { learning } \\
\mathrm{n}=317-345\end{array}$ \\
\hline $\begin{array}{l}\text { 1. } \begin{array}{l}\text { Designing of } \\
\text { instruction }\end{array} \\
\end{array}$ & 3.92 & .856 & & $\mathrm{~F}=6.95^{* * *}$ & $.14^{\star *}$ \\
\hline $\begin{array}{l}\text { 2. Critical reflection } \\
\text { on own work }\end{array}$ & 3.76 & .894 & $\mathrm{~F}=3.07^{* *}$ & & $.37^{* * *}$ \\
\hline $\begin{array}{l}\text { 3. Becoming aware } \\
\text { of ethical basis } \\
\text { of teaching } \\
\text { profession }\end{array}$ & 3.71 & .914 & & & $.21^{* *}$ \\
\hline $\begin{array}{l}\text { 4. Life-long } \\
\text { professional } \\
\text { growth }\end{array}$ & 3.69 & .896 & $\mathrm{~F}=3.29 * * *$ & & $.23^{* *}$ \\
\hline $\begin{array}{l}\text { 5. Self-evaluating of } \\
\text { own teaching }\end{array}$ & 3.67 & .934 & $\mathrm{~F}=4.18^{\star * *}$ & & $.25^{* * *}$ \\
\hline $\begin{array}{l}\text { 6. Using teaching } \\
\text { methods }\end{array}$ & 3.54 & .764 & & & $.32^{* * *}$ \\
\hline $\begin{array}{l}\text { 7. } \begin{array}{l}\text { Development of } \\
\text { own educational } \\
\text { philosophy }\end{array} \\
\end{array}$ & 3.46 & .977 & $\mathrm{~F}=3.13^{* *}$ & $\mathrm{~F}=9.84^{\star * *}$ & $.29^{* * *}$ \\
\hline $\begin{array}{l}\text { 8. Mastering } \\
\text { academic contents } \\
\text { of curriculum }\end{array}$ & 3.44 & .926 & & & $.11^{*}$ \\
\hline $\begin{array}{l}\text { 9. Independent } \\
\text { management } \\
\text { of teachers' } \\
\text { tasks }\end{array}$ & 3.39 & .926 & & $\mathrm{~F}=6.66^{* * *}$ & $.17^{* *}$ \\
\hline
\end{tabular}




\begin{tabular}{|c|c|c|c|c|c|}
\hline $\begin{array}{l}\text { 10. Commitment } \\
\text { to teaching } \\
\text { profession }\end{array}$ & 3.39 & .948 & & & $.24^{\star * *}$ \\
\hline $\begin{array}{l}\text { 11. Research of own } \\
\text { work }\end{array}$ & 3.29 & 1.031 & $\mathrm{~F}=2.13$ * & & $.26^{* * *}$ \\
\hline $\begin{array}{l}\text { 12. Education of a } \\
\text { student's whole } \\
\text { personality }\end{array}$ & 3.23 & .943 & $\mathrm{~F}=3.34^{\star *}$ & $\mathrm{~F}=10.91 * * *$ & $.29^{* * *}$ \\
\hline $\begin{array}{l}\text { 13. Critical assessment } \\
\text { of teacher } \\
\text { education }\end{array}$ & 3.23 & 1.153 & & & $.37^{\star * *}$ \\
\hline $\begin{array}{l}\text { 14. Confronting } \\
\text { multiculturalism }\end{array}$ & 3.16 & .985 & & $\mathrm{~F}=6.80^{* * *}$ & $.11^{\star}$ \\
\hline $\begin{array}{l}\text { 15. Confronting } \\
\text { changing } \\
\text { circumstances of a } \\
\text { school } \\
\end{array}$ & 3.07 & .914 & & $\mathrm{~F}=3.99 * * *$ & $.34^{* * *}$ \\
\hline $\begin{array}{l}\text { 16. Supporting a } \\
\text { learner's individual } \\
\text { growth }\end{array}$ & 3.07 & .917 & & $\mathrm{~F}=2.32$ * & $.32^{* * *}$ \\
\hline $\begin{array}{l}\text { 17. Management } \\
\text { of classroom } \\
\text { interaction }\end{array}$ & 3.03 & .926 & & $\mathrm{~F}=2.13^{*}$ & $.19^{\star *}$ \\
\hline $\begin{array}{l}\text { 18. Self-regulated } \\
\text { learning }\end{array}$ & 3.01 & .922 & & $\mathrm{~F}=3.67^{\star *}$ & $.39^{* * *}$ \\
\hline $\begin{array}{l}\text { 19. Differentiating of } \\
\text { teaching }\end{array}$ & 3.00 & .903 & $\mathrm{~F}=1.84$ * & $\mathrm{F}=13.38^{* * *}$ & $.15^{\star *}$ \\
\hline $\begin{array}{l}\text { 20. Intercultural } \\
\text { education }\end{array}$ & 3.00 & 1.001 & $\mathrm{~F}=2.13^{\star}$ & & $.24^{\star * *}$ \\
\hline $\begin{array}{l}\text { 21. Developing } \\
\text { applications } \\
\text { of modern } \\
\text { information } \\
\text { technology }\end{array}$ & 2.98 & .956 & $\mathrm{~F}=2.21$ * & & $.34^{\star * *}$ \\
\hline $\begin{array}{l}\text { 22. Preparing students } \\
\text { for a future } \\
\text { society }\end{array}$ & 2.95 & .941 & & & $.32^{* * *}$ \\
\hline $\begin{array}{l}\text { 23. Promoting equity } \\
\text { of sexes }\end{array}$ & 2.95 & 1.054 & & & $.28^{* * *}$ \\
\hline $\begin{array}{l}\text { 24. Developing of } \\
\text { school curriculum }\end{array}$ & 2.94 & .968 & $\mathrm{~F}=2.78^{* *}$ & $\mathrm{~F}=7.26^{* * *}$ & $.30^{* * *}$ \\
\hline $\begin{array}{l}\text { 25. Evaluating } \\
\text { and grading of } \\
\text { students }\end{array}$ & 2.93 & .927 & & $\mathrm{~F}=231$ * & $.19^{\star *}$ \\
\hline $\begin{array}{l}\text { 26. Revising } \\
\text { students' learning } \\
\text { environments }\end{array}$ & 2.90 & .934 & $\mathrm{~F}=2.30^{* *}$ & $\mathrm{~F}=7.92 * * *$ & $.40^{* * *}$ \\
\hline $\begin{array}{l}\text { 27. Readiness for } \\
\text { media education }\end{array}$ & 2.89 & .906 & & & $.31^{* * *}$ \\
\hline $\begin{array}{l}\text { 28. Providing } \\
\text { readiness for } \\
\text { students for daily } \\
\text { life }\end{array}$ & 2.88 & .897 & & & $.28^{* * *}$ \\
\hline
\end{tabular}




\begin{tabular}{|c|c|c|c|c|c|}
\hline $\begin{array}{l}\text { 29. Working as a } \\
\text { change agent in a } \\
\text { society }\end{array}$ & 2.81 & 1.023 & & $\mathrm{~F}=4.78^{* * *}$ & $.40^{* * *}$ \\
\hline $\begin{array}{l}\text { 30. Evaluating } \\
\text { students' learning } \\
\text { capacity }\end{array}$ & 2.77 & .852 & & & $.24^{* * *}$ \\
\hline $\begin{array}{l}\text { 31. Doctoral studies } \\
\text { after MA in } \\
\text { education }\end{array}$ & 2.63 & 1.024 & $\mathrm{~F}=2.30^{\star *}$ & & $.26^{* * *}$ \\
\hline $\begin{array}{l}\text { 32. Cooperation with } \\
\text { representative of } \\
\text { cultural life }\end{array}$ & 2.42 & .976 & $\mathrm{~F}=2.9^{* *}$ & $\mathrm{~F}=4.96^{* * *}$ & $.22^{\star *}$ \\
\hline $\begin{array}{l}\text { 33. Acting in conflict } \\
\text { situations (as } \\
\text { mobbing) }\end{array}$ & 2.37 & .935 & & & $.23^{* *}$ \\
\hline $\begin{array}{l}\text { 34. Working in a } \\
\text { school community } \\
\text { ( teaching staff } \\
\text { and other school } \\
\text { personnel) }\end{array}$ & 2.28 & .922 & & $\mathrm{~F}=2.48^{\star}$ & $.11^{\star *}$ \\
\hline $\begin{array}{l}\text { 35. Working with a } \\
\text { student welfare } \\
\text { group }\end{array}$ & 2.28 & .877 & & & $.22^{* * *}$ \\
\hline $\begin{array}{l}\text { 36. Cooperative action } \\
\text { research }\end{array}$ & 2.28 & 1.008 & $\mathrm{~F}=2.90^{* *}$ & $\mathrm{~F}=7.55^{* * *}$ & $.32^{* * *}$ \\
\hline $\begin{array}{l}\text { 37. Cooperation with } \\
\text { parents }\end{array}$ & 2.26 & .898 & & & $.14^{*}$ \\
\hline $\begin{array}{l}\text { 38. Cooperation with } \\
\text { representatives of } \\
\text { work life } \\
\end{array}$ & 1.85 & .792 & $\mathrm{~F}=2.30^{\star *}$ & $\mathrm{~F}=3.78^{* *}$ & $.29^{* * *}$ \\
\hline $\begin{array}{l}\text { 39. Management } \\
\text { of tasks outside } \\
\text { the classroom } \\
\text { (keeping on } \\
\text { eye on students } \\
\text { during recess, } \\
\text { school festivals, } \\
\text { trips) morning } \\
\text { assemblies, } \\
\text { etc.) }\end{array}$ & 1.79 & .813 & & $\mathrm{~F}=685^{\star * *}$ & $.28^{* * *}$ \\
\hline $\begin{array}{l}\text { 40. Administrative } \\
\text { tasks (information } \\
\text { letters, reports, } \\
\text { student transfers } \\
\text { to other groups or } \\
\text { schools) diaries) }\end{array}$ & 1.67 & .771 & & $\mathrm{~F}=3.56^{* *}$ & .04 \\
\hline
\end{tabular}

Student teachers from different study phases were involved in the survey. When comparing differences using one-way ANOVA there were significant differences in 15 skills according to the number of years the students had participated in TE (Table 2): more years meant more competences. Professional competence areas such as Critical reflection on one' own work $\left(\mathrm{F}=3.07^{* *}\right)$, Life-long professional growth $(\mathrm{F}=3.29$ 
$\left.{ }^{* *}\right)$, Self-evaluating of one's own teaching $\left(\mathrm{F}=4.18^{* * *}\right)$, and Development of one's own educational philosophy $\left(\mathrm{F}=3.13^{* *}\right)$ need more time and are better achieved in later years of study. Many practical skills, e.g., Using teaching methods and mastering academic contents of the curriculum, and even Independent management of teachers' tasks, do not have effects caused by the number of years of study. There are neither significant differences caused by the number years of study in the following professional competences: Becoming aware of the ethical basis of the teaching profession and Commitment to the teaching profession. These qualities provide evidence that teacher education has succeeded in laying sustainable grounds for student teachers' development from the first years of teacher education.

\section{Differences between class teachers and subject teachers}

When comparing differences between class teachers and subject teachers using one-way ANOVA there were significant differences in 20 skills (Table 2). Subject teachers who teach mainly in lower and upper secondary schools (grade levels 7-12) have much fewer pedagogical competences than class teachers. There are very strong differences in the following competences: Education of a student's whole personality $\left(\mathrm{F}=10.91^{* * *}\right)$, Confronting multiculturalism $\left(\mathrm{F}=6.8 \mathrm{O}^{* * *}\right)$, Differentiating of teaching $\left(\mathrm{F}=13.38^{* * *}\right)$, Designing of instruction $(\mathrm{F}=6.95$ $\left.{ }^{* *}\right)$, Developing of school curriculum $\left(\mathrm{F}=7.26^{* *}\right)$, Revising students' learning environments $\left(\mathrm{F}=7.92^{* * *}\right)$, and Development of one's own educational philosophy $\left(\mathrm{F}=9.84^{* * *}\right)$. As above, there are no significant differences in the professional competences of Becoming aware of the ethical basis of the teaching profession and Commitment to the teaching profession. Even though there are also positive results in many fundamental basic skills of secondary student teachers, they differ in 20 skills when compared to class teachers. The result highlights an urgent necessity to develop secondary school teacher education in many areas of teachers' professional competences.

\section{Active learning}

The students assessed that they had the following active learning experience the most often (Table 3): they worked intensively on their assignments, applied knowledge, and tried to understand matters and phenomena even though it required extra time. They were tutored if needed, but otherwise they worked independently or in peer 
groups. They discussed the best solution for the assignments together and self-evaluated their own products. They also sought a great deal of additional knowledge. They had these experiences almost every week.

Almost the same questionnaire (18 of the same questions) was used in a Finnish study of student teachers at three universities in 1995 (Niemi, 2002). We can see that in 15 years there has been a big shift towards more active learning in teacher education. In the mid 1990s, active learning methods were used once or twice a year and web environments almost never. Now, in 2010, students have active learning methods every month or every week. The scale was the same. In the earlier surveys there were only 5 active learning methods that were used about once in a month: Students worked intensively on their assignments $(M=3.54)$, Students were tutored if needed, but otherwise they worked independently or in peer groups $(M=3.12)$, Students discussed the best solution for the assignments together $(M=3.08)$, Students self-evaluated their own products $(M=3.23)$, Students set objectives for themselves and their learning $(\mathrm{M}=3.37)$, and Students worked in groups on problem-solving tasks $(M=3.26)$. In 2010, almost all active learning methods were used at least once a month or weekly.

Table 3. Active learning in teacher education. $1=$ almost never, $2=$ once or twice a year, $3=$ about once a month, $4=$ about once a week, $5=$ nearly daily.

\begin{tabular}{|c|c|c|}
\hline Active Learning methods & $\mathbf{M}$ & SD \\
\hline 1. We work intensively on our assignments. & 3.72 & .95 \\
\hline 2. We have to apply knowledge. & 3.60 & 1.12 \\
\hline $\begin{array}{l}\text { 3. We try to understand matters and phenomena even though it } \\
\text { takes time. }\end{array}$ & 3.49 & 1.09 \\
\hline $\begin{array}{l}\text { 4. We are tutored if needed, but otherwise we work } \\
\text { independently or in peer groups. }\end{array}$ & 3.48 & 1.05 \\
\hline 5. We discuss the best solution for the assignments together. $(+)$ & 3.44 & 1.10 \\
\hline 6. We self-evaluate our own products. & 3.43 & 1.06 \\
\hline 7. We seek a lot of additional knowledge. & 3.43 & 1.12 \\
\hline 8. We set objectives for ourselves and our learning. & 3.41 & 1.05 \\
\hline 9. We know how to develop our own learning. & 3.35 & 1.11 \\
\hline 10. We work in groups on problem-solving tasks. $(+)$ & 3.25 & 1.12 \\
\hline $\begin{array}{l}\text { 11. We independently produce, e.g., reviews, outlines of sessions, } \\
\text { and presentations }\end{array}$ & 3.24 & .92 \\
\hline
\end{tabular}




\begin{tabular}{|l|r|r|}
\hline $\begin{array}{l}\text { 12. We have to seek almost all knowledge independently from } \\
\text { different information sources. }\end{array}$ & 3.20 & 1.15 \\
\hline 13. We use and apply knowledge very critically. & 3.19 & 1.26 \\
\hline $\begin{array}{l}\text { 14. We experiment and elaborate on new solutions to roblems. } \\
\text { 15. We independently plan and carry out learning contracts for } \\
\text { which we are responsible. }\end{array}$ & 3.08 & 1.09 \\
\hline $\begin{array}{l}\text { 16. We use electronic databases and social media to seek } \\
\text { knowledge for our assignments. }\end{array}$ & 2.94 & 1.24 \\
\hline $\begin{array}{l}\text { 17. We seek knowledge off campus. } \\
\text { 18. We have to elaborate on our assignments independently or in } \\
\text { peer groups only based on a general theme. }\end{array}$ & 2.63 \\
\hline $\begin{array}{l}\text { 19. We have to take responsibility for planning and carrying out } \\
\text { fairly large projects. }\end{array}$ & 2.40 & 1.05 \\
\hline $\begin{array}{l}\text { 20. We plan together the content and working methods of study } \\
\text { unit. }\end{array}$ & 2.39 & 1.30 \\
\hline
\end{tabular}

The active learning scale was analysed using correlations and factor analysis with Varimax and Promax (oblique) rotations. Correlations of all active learning items were significant (most over .30). It would have been possible to extract two dimensions of active learning: (1) Independent knowledge inquiry and creation individually and in groups and (2) Critical approach to knowledge and one's own learning. However, these factors correlated very highly $(>.70)$ and therefore only one combined variable was constructed containing all 20 items $(\mathrm{alpha}=.93)$. This variable is used when searching for relationships between active learning and professional competence.

Active learning is related to professional competences in a very interesting way (Table 2). The strongest relationships exist between active learning and professional competences in tasks that require a strong reflective orientation and commitment to the teaching profession. Active learning has the strongest correlations $(.37-.40)$ with the variables (27) Revising students' learning environments, (25) Working as a change agent in a society, (34) Self-regulated learning, (35) Critical reflection on one's own work, and (24) Critical assessment of teacher education.

Students were asked to describe their best experiences in active learning. The writings of 253 students were analysed using content analysis techniques. Six main categories could be found. These are not separate but integrated with each other in many ways. The categories are:

- Collaborative working culture, active discussions with peers and professor/supervisors, knowledge sharing in coursework, 
examinations where a group is responsible for outcomes. (92 notes, $36 \%$ from 253 )

- $\quad$ Teaching practice, to apply knowledge to teaching and learning, requiring one's own engagement and commitment. This category also consisted of many notes about encouraging feedback from supervisors. The important features in teaching practice were opportunities to experiment and to work with pupils in schools. Many descriptions also consisted of an idea about collaboration with student teachers, supervisors and teachers responsible for theoretical studies of pedagogy. (76 notes, $30 \%$ from 253)

- Opportunity to own applications, freedom to make one's own plans, design or develop large units for one's own or pupils' learning. (48 notes, 19\% from 253)

- $\quad$ Research studies including writing BA and MA thesis, commitment to inquiry, learning a critical approach to knowledge. (35 notes, $13 \%$ from 253)

- The large course units or programmes that had been implemented throughout with active learning methods focusing on understanding phenomena in life and connections between different disciplines in a new and deeper way. (14 notes, $6 \%$ from 253)

- $\quad$ Subject matter projects or subject matter pedagogy related to different school subjects (39 notes, $15 \%$ from 253), requiring independent inquiry or collaborative knowledge creation.

The students surveyed had a lot of active learning experience. The study provides evidence that there is a relationship between active learning and high level professional competences: the more active learning, the higher the professional skills and vice versa. The best active learning experiences emerge in collaborative work and study culture. Teaching practice is a very important forum for active learning. Students also appreciate the freedom to experiment and design their own learning paths.

\section{Research studies in teacher education}

Student teachers were asked to assess how research studies had contributed to their professional development. The most important abilities they had learnt through research studies were: Critical thinking, Independent thinking, Inquiring, Scientific literacy and 
Questioning phenomena and knowledge. The general picture is very positive. Almost all of the variables have a mean >.3.oo. Student teachers see research studies as valuable for the teaching profession and see their future work in this as a continuous developmental task.

Table 4 Research studies in student teachers professional development.

$1=$ very little, $2=$ little, $3=$ somewhat, $4=$ much $5=$ very much $(\mathrm{N}=328$ 338 , from which 51 students answered $\mathrm{o}=\mathrm{I}$ have not yet had research studies - these students have been subtracted)

\begin{tabular}{|c|c|c|}
\hline $\begin{array}{l}\text { How research studies, including research methodological } \\
\text { studies and BA/MA theses, have promoted teachers' } \\
\text { professional development }\end{array}$ & $\begin{array}{r}M \\
(\mathrm{~N}=\mathbf{2 7 7 - 2 8 8}) \\
\end{array}$ & SD \\
\hline Development of readiness for inquiry & 3.82 & .91 \\
\hline Development of independent thinking & 3.72 & .90 \\
\hline Understanding research literature & 3.67 & .95 \\
\hline Questioning knowledge and phenomena & 3.55 & .95 \\
\hline Development of critical thinking & 3.55 & 1.01 \\
\hline Development of methods for knowledge creation & 3.45 & 1.02 \\
\hline $\begin{array}{l}\text { Considering teaching profession of as continuous } \\
\text { developmental task }\end{array}$ & 3.43 & 1.12 \\
\hline Conscientiousness of error sources of research & 3.37 & 1.03 \\
\hline Considering working as a teacher as continuous growth & 3.27 & 1.18 \\
\hline $\begin{array}{l}\text { Understanding significance of research in classrooms and } \\
\text { schools }\end{array}$ & 3.23 & 1.11 \\
\hline $\begin{array}{l}\text { Becoming conscious of societal significance of teaching } \\
\text { profession }\end{array}$ & 3.19 & 1.14 \\
\hline Development of my own personality & 3.13 & 1.16 \\
\hline Applying research knowledge to practice & 3.14 & 1.08 \\
\hline Increasing societal consciousness & 3.14 & 1.07 \\
\hline Increasing responsibility in teaching profession & 3.11 & 1.17 \\
\hline Understanding students' learning processes & 3.09 & 1.17 \\
\hline Increasing a teacher's ethical responsibility & 3.00 & 1.16 \\
\hline Research-based development of schools & 2.93 & 1.08 \\
\hline Clarification of significance of a teacher's work & 2.89 & 1.11 \\
\hline Development of educational responsibility & 2.88 & 1.12 \\
\hline
\end{tabular}

Students had an opportunity to give their additional comments: What else would you like to say about research studies? Their 
comments were analysed with content analysis.

Amongst class teachers $(n=88)$ comments in the following categories could be found: 1) Very important and useful for teaching profession (25 comments), 2) Too many research studies, they took time from other studies (22 comments), 3) Supervision was weak (14 comments), 4) Weak quality of studies and problems in organising and scheduling them with other studies (14 comments), and 5) Too separate from practice ( 9 comments).

Secondary school teachers $(n=50)$ did not criticise the quantity of studies and there were only 6 comments suggesting that research studies are too separate from practice. Instead, there were many (16) critical comments on the quality of studies and how they were organised. Some students felt that research studies in pedagogy had been very superficial. The major problem was that there was a lack of cooperation between their subject matter faculty and the pedagogical faculty. This overloaded students and caused a lot of problems. There were also positive comments (12) in which students emphasised the importance of these studies for the teaching profession.

\section{Summary and conclusions}

Finnish teacher education has a long history in educating high standard professionals. Typical features have been commitment to a research-based orientation and promoting teachers' work for contexts that require autonomous expertise. The present research provides important information about the strengths and weaknesses of current Finnish teacher education. Finnish student teachers are committed to the teaching profession and are aware of the ethical grounds of teaching. Student teachers assess that they have high competences for their profession. They have good skills in planning teaching and using different teaching methods. They are aware of their own teaching philosophy and their professional responsibilities. They consider the research component of TE as valuable for their independent and critical thinking. They are very engaged in studies. More training for cooperation with parents, representatives of work life and cultural partners is also needed in teacher education, as well as for the preparation of teachers to act in conflict situations (such as mobbing). A common feature of all of these skills is cooperation with partners outside the school community or tasks outside classrooms.

Students have a lot of active learning experiences. The study 
provides evidence that there is a strong relationship between active learning and high level professional competences: the more active learning, the higher professional skills and vice versa. The best active learning experiences emerge in collaborative working and study culture. Students appreciate having the freedom to experiment and design their own applications of active learning.

The research component in teacher education is important to the majority of students, but there are also student teachers who are critical of these studies. Most critical voices are related to the quality of the studies or to practical arrangements (e.g., timing) and there is also a need to develop research studies in such a way that students can see their relevance to teachers' professional work.

Finnish pre-service teacher education seems to function very well and to be effective in training professionals. Finnish teacher education has been assessed several times and its development is based on these reviews. The present study provides new information for further development. This study also provides scenarios and evidence regarding what research based-teacher education is and how to develop teacher education by implementing the following principles:

- $\quad$ Teachers need a profound knowledge of the most recent advances in research in the subjects they teach. In addition, they need to be familiar with the latest research on how something can be taught and learnt.

- $\quad$ Teacher education in itself should also be an object of study and research. This research should provide knowledge about the effectiveness and quality of teacher education.

- The aim is for teachers to internalise a research-orientated attitude towards their work. This means that teachers learn to take an analytical and open-minded approach to their work and that they develop their teaching and learning environments in a systematic way.

\section{References}

European University Association (2007). Creativity in Higher Education. Report on the EUA Creativity Project 2006-2007. Brussels: European University Association.

Buchberger, F., De Corte, E., Groombridge, B., \& Kennedy, M. (1994). Educational studies and teacher education in Finnish universities. A commentary by an international review team. Helsinki: Ministry of Education, Division of educational and research policy, 14. The Committee Report (1994). Educational sciences towards the future. The final report of the Committee for the Evaluation and Development of Educational Sciences. Helsinki: 
Ministry of Education, Division of educational and research policy, 16. (in Finnish, abstract in English).

Darling-Hammond, L. (2005). Teaching as a profession: Lessons in teacher preparation and professional development. Phi Delta Kappan, 8(3), 237-240.

Darling-Hammond, L. (2010). The flat world and education. How America's commitment to equity will determine our future. New York: Teachers College.

Davenport, T. H., \& Prusak. L. (1998). Working Knowledge: How Organizations Manage

What They Know. Cambridge, MA: Harvard Business School Press.

Dreyfus, H. L., \& Dreyfus S. E. (1986). Mind over machine. The Power of Human Intuition and Expertise in the Era of Computer. New York: Blackwell.

Finnish Higher Education Evaluation Council (2011). From http://www.kka.fi/?l=en\&s=1. Isopahkala-Bouret, U. (2005). Joy and struggle for renewal: A Narrative Inquiry into Expertise in Job transitions. University of Helsinki, Faculty of Behavioural Sciences, Department of Education, Research report 201.

Jussila, J., \& Saari. S. (1999). Opettajankoulutus tulevaisuuden tekijänä. Korkeakoulujen arviointineuvoston julkaisuja 11. Edita: Helsinki.

Ministry of Education (2007). Committee report Teacher education 2020 (Chair by Hannele Niemi). Helsinki.

Niemi, H. (1995) Teacher professional development, part 2. Evaluation of teacher education in the frame of reference of learning experiences and new professionalism. Reports from the Department of Teacher Education in Tampere University A 3. (In Finnish, abstract in English).

Niemi, H. (1996). Effectiveness of teacher education. A theoretical framework of communicative evaluation and the design of a Finnish research project. In H. Niemi \& K. Tirri (Eds.), Effectiveness of teacher education. New challenges and approaches to evaluation (pp. 11- 32). Reports from the Department of Teacher Education in Tampere University A 6. Niemi, H. (1999). ICT in Teacher education. In M. Sinko \& E. Lehtinen (Eds.), The Challenges of ICT (pp. 145-173).

Niemi, H (2002). Active Learning - A cultural change needed in teacher education and in schools. Teaching and Teacher Education, 18, 763-780.

Niemi, H., \& Jakku-Sihvonen, R. (2006). Research-based teacher education. In R. JakkuSihvonen \& H. Niemi (Eds.), Research-based teacher education in Finland - reflections by Finnish teacher educators (pp. 31-50). Turku: Finnish Educational Research Association. Niemi, H., \& Kemmis, S. (1999). Communicative evaluation: evaluation at the crossroads. Lifelong Learning in Europe (LLinE), IV(1), 55-64.

Niemi, H., \& Kohonen, V. (1995). Towards new professionalism and active learning in teacher development: Empirical findings on teacher education and induction. University of Tampere. Department of Teacher Education. Research series A 2.

Nonaka, I., \& Toyama, R. (2003). The Knowledge-Creating Theory Revisited: knowledge creation as a synthesizing process. Knowledge Management Research \& Practice, 1, 2-10. 
From http://dx.doi.org/10.1057/palgrave.kmrp.8500001.

Pintrich, P. R., \& McKeachie, W .J. (2000). A Framework for Conceptualizing Student Motivation and Selfregulated Learning in the College Classroom. In P.R. Pintrich \& P. Ruohotie (Eds.), Conative Constructions and Self-regulated Learning (pp. 31-50).

Hämeenlinna, Finland: RCVE.

Scardamalia, M. (2002). Collective cognitive responsibility for the advancement of knowledge. In B. Smith (Ed.), Liberal education in a knowledge society (pp. 67-98).

Chicago: Open Court.

Scardamalia, M., \& Bereiter, C. (2003). Knowledge building. In Encyclopedia of education (2nd ed., pp. 1370-1373). New York, USA: Macmillan Reference.

Schön, D. A. (1991). The Reflective Turn: Case Studies In and On Educational Practice. New York: Teachers Press, Columbia University.

Sfard, A. (1998). On Two Metaphors for Learning and the Dangers of Choosing Just One.

Educational Researcher, 27(2), 4-13.

Smyth, J. (1995). Introduction. In J. Smyth (Ed.), Critical discourses on teacher development (pp-1-19). Great Britain: Cassell, Wellington House.

Tabachnick, B. R., \& Zeichner, K. M. (1991). Reflections on reflective teaching. In B.

R. Tabachnick \& K. M. Zeichner (Eds.), Issues and practices in inquiry oriented teacher education (pp. 1-20). New York: Falmer Press.

Vokke project 2005, The Finnish project related to the European Bologna process implementation. Retrieved March, 14, 2011 from http://www.helsinki.fi/vokke/english. htm. 


\section{Biographical note}

Hannele Niemi, PhD, is Professor of Education (1998-) and Vice-Rector for academic affairs at the University of Helsinki (20032009). She has been Dean, Vice-Dean and Head of the Faculty of Education at the University of Helsinki and Professor of Education in three other Finnish Universities. She has been Visiting Scholar at Michigan State University (1989) and Stanford University (2010). She has been a member of many national and international scientific councils (e.g. European Science Foundation, Academy of Finland) and a member of the Steering Committee for the British national research programme on teaching and learning (TLRP, 2003-2008), and was nominated Director of the Finnish national research programme "Life as Learning" 2002-2006. She has been Chair or Board Member of the CICERO Learning Network for multidisciplinary research on learning (2005-). She has been a member of the Finnish Higher Education Evaluation Council (2004-2009). She is an advisor and reviewer for many scientific journals and has served as Chair or a researcher in many national and international evaluation projects for the development of higher education, educational research and teacher education. She has contributed in many EU projects as an expert or researcher and served as a key note lecturer in several international forums. Her main research interest areas are teachers' professional development, moral education and technology-based learning environments. She has published several articles and books on education in Finland and Finnish teacher education (e.g. Research-Based Teacher Education in Finland, 2006 and Education as a Societal Contributor 2007) and contributed to many international education research publications (e.g. Evidence in Education, Linking Research and Policy, OECD/CERI 2007). 